九州大学学術情報リポジトリ

Kyushu University Institutional Repository

\title{
Application of Geographic Information System (GIS-IDRISI) for Assessing Land Use Risks on Sediment Yields
}

Munir, Ahmad

Laboratory of Watershed Envirornmental Science and Technology, Kyushu University

Suripin

Dept. of Civil Engineering, Faculty of Engineering, Diponegoro University

Abdullah, Muh. Nurdin

Faculty of Agriculture and Forestry, Hasanuddin University

Marutani, Tomomi

Faculty of Agriculture, Kyushu University

https://doi.org/10.5109/24347

出版情報：九州大学大学院農学研究院紀要. 44 (3/4)，pp.463-471，2000-02. Kyushu University バージョン：

権利関係 : 


\title{
Application of Geographic Information System (GIS-IDRISI) for Assessing Land Use Risks on Sediment Yields
}

\author{
Ahmad Munir ${ }^{\text {) }}$, Suripin ${ }^{2)}$, Muh. Nurdin Abdullah ${ }^{3)}$ and Tomomi Marutani ${ }^{4)}$ \\ Jaboratory of Watershed Environmental Sciencc and l'echnology, \\ Kyushu University, Fukuoka 812-8581, Japan \\ (Received October 29, 1999 and accepted November.5, 1999)
}

\begin{abstract}
The land usc development on the catchment area have to consider the sustainability of the natural resources: particularly water and soil fertility. Therefore, the risks of lark use development must ho minimized. This paper presents a methodology and analysis of the land use risks on sediment yield from a catchmont area arud propose some suggestions to maintain the catchment arca function. The universal soil loss equation (USLE) in combination with IDRISI software package was used in this study. Five thematic maps of USLE parameters; rainfall erosivity $(R)$, soil erodibilily factor $(K)$, length-slopc-stcopness factor $(L S)$, land use factor $(C)$, and conservation factor $(P)$ were constructed by digitizing them on computer data base with an element size of $200 \times 200 \mathrm{ml}^{3}$. The spatial and temporal changes on catchutent area (land use and sediment yield) were obtained by comparing two set of maps from different period. The proposed ntethod is appliced at Wonogiri eatchmert area in Indortesia. From this study, it was found that there are significant risks of the land use on the scdiment yields and the existing land use have to be modified to reduce the sediment yields.
\end{abstract}

\section{INTRODUCTION}

The land use pattern is a critical aspect in the overall water resources project. The purpose of an appropriate land use planning is to maximize land productivity, in accordance with minimum risks of land use management. Land use risks analysis is an important task, particularly in medium to large catchment area in tropical, and especially in densely populated area like in most parts of Indonesia. In order to assess the effect of land use risks in a catchment area, the described in this paper methodology was developed. The integration of digitization map on computer data base with an element, size of $200 \times 200 \mathrm{~m}^{2}$ is used to assess the soil erosion in the study area. The spatial and temporal changes on catchment, area (land use and gross erosion) were obtained by comparing two set of maps from different period.

\section{STUDY AREA}

The proposed method was applied in the Wonogiri catchment area, which is located in the Southeast part of the Central Java in the mountainous area of Lpper Solo Catchment area (Figure 1). The catchment area covers an area of $1305 \mathrm{~km}^{2}$, and

\footnotetext{
1: and Paculty of Agriculture and Forestry Hasanuddin Lniversity-Indonesia.

${ }^{21}$ Dept. of Civil Engineering, Faculty of Engineering, Diponegoro University- Indonesia

"Faculty of Agriculture, Kyushu Lniversity-Japan
} 


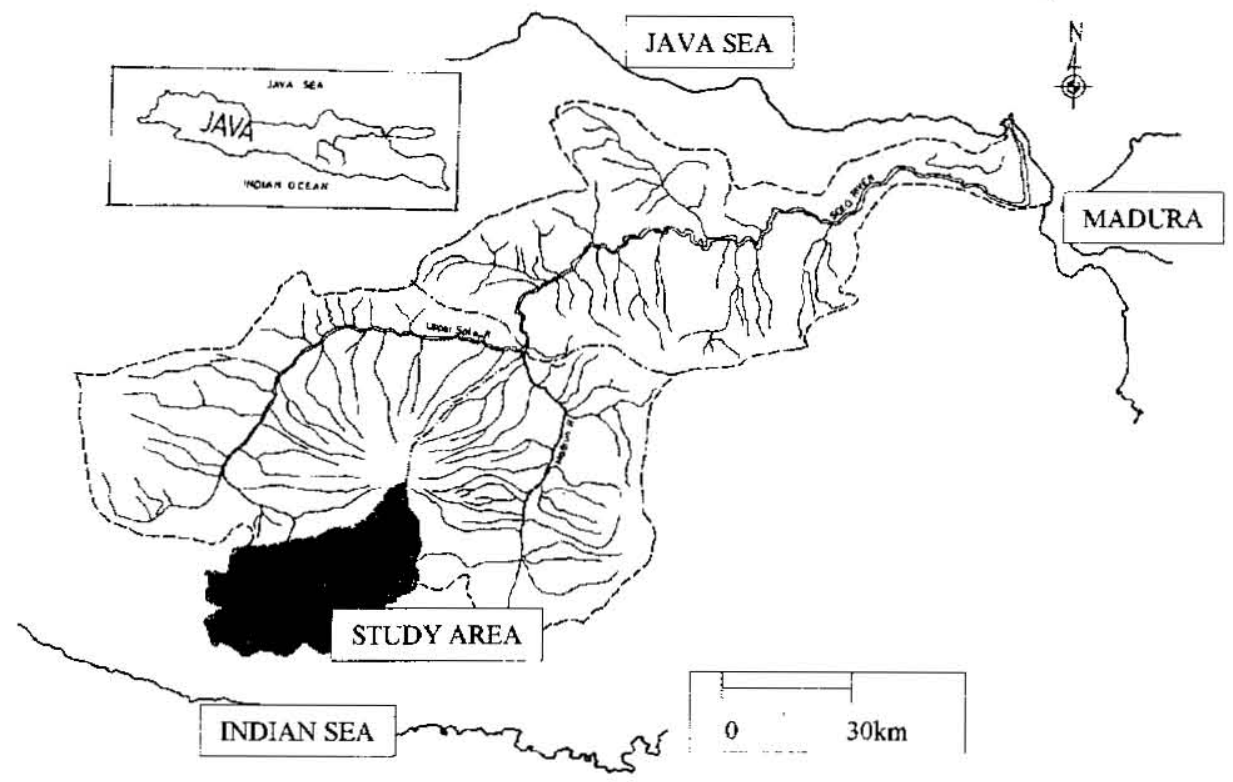

Fig. 1. Location map of the study area

composed of six sub-basins: Keduang $\left(417.36 \mathrm{~km}^{2}\right)$, Tirtomoyo or Wiroko $\left(229.36 \mathrm{~km}^{2}\right)$, Beling or Temon $\left(65.04 \mathrm{~km}^{2}\right)$, Upper Solo $\left(203.52 \mathrm{~km}^{2}\right)$, Alang $\left(163.80 \mathrm{~km}^{2}\right)$ and Wuryantoro-Ngunggahan $\left(137.44 \mathrm{~km}^{2}\right)$. It is closed catchment area, surrounded by continuous mountain ranges; Merbabu and Lawu Mounts in the West, South Mountain in the South, Willis Mount in the East. and Kendeng Mountain in the North. The catchment area is located between $7^{\circ} 32^{\prime} \mathrm{S}-8^{\circ} 12^{\prime} \mathrm{S}$ and $110^{\circ} 40^{\prime} \mathrm{E}-111^{\circ} 18^{\prime} \mathrm{E}$. It experiences an Indo-Australia monsoon with mean annual precipitation of $1850 \mathrm{~mm}, 85 \%$ of which fall during wet season (November-April).

The main river structure in this area is Gajah Mungkur (Wonogiri) reservoir, which was built in 1976 and essentially completed in 1982, while the reservoir impoundment was started in July 1980 (DGM, 1981). The reservoir is a multi-purpose project, majoring on flood control and irrigation (Citra Mandala Agrrilrans, 1993). The dam was rock-fill with an impervious core, 40 meter high with a total capacity of $720 \times 106 \mathrm{~m}^{3}$ at elevation $138.30 \mathrm{~m}$ (Virama Karya, 1992). Dead storage of $120 \times 10^{n} \mathrm{~m}^{3}$ is provided below elevation of $127.00 \mathrm{~m}$. A bottom outlet of $1.95 \mathrm{~m}$ in diameter and completed with a hollow jet valve was installed at an invert level of $116.00 \mathrm{~m}$. This outlet is used only during the case of reparation of power generation facilities, having a maximum capacity of $35.0 \mathrm{~m} / \mathrm{s}$.

Based on several hydrographic surveys (echo-sounding and/or terrestrial survey), it was found that the reservoir is silted up seriously (P4-PU, 1992). During 14 years in operation (1980-1993) the total capacity has lost $18 \%$, or $1.3 \%$ annually (Table 1). It is much higher than that estimated in the design $\left(1.5 \times 10^{5} \mathrm{~m}^{3}\right)$. So, the proposed life time of 100 years would hardly be achieved. 
Table 1. Reduction of Gajah Mungkur reservoir capacity

\begin{tabular}{lcccc}
\hline Dide of survey & $\begin{array}{c}\text { Remaining } \\
\text { capacity } \\
\left(10^{*} \cdot \mathrm{m}^{3}\right)\end{array}$ & $\begin{array}{c}\text { Accumulative } \\
\text { deposition } \\
\left(10^{5} \cdot \mathrm{m}^{3}\right)\end{array}$ & $\begin{array}{c}\text { Deposition } \\
\text { rate } \\
\left(10^{5} \cdot \mathrm{m}^{3} / \mathrm{yr}\right)\end{array}$ & $\begin{array}{c}\text { Equivalent } \\
\text { sediment yield } \\
\text { t/ha/year }\end{array}$ \\
\hline July 1980 (initial) & 720.00 & 0 & - & - \\
October 1984 & 678,32 & 41,68 & 9.62 & 84.6 \\
September 1985 & 654,57 & 65,43 & 12.46 & 109.6 \\
August 1987 & 635,62 & 84,38 & 11.77 & 103.5 \\
Dec:ember 1992 & 610,61 & 109,39 & 8.75 & 76.9 \\
Decomber 1993 & 588,13 & 131,87 & 9.77 & 85.9 \\
\hline
\end{tabular}

Sources: P4-PBS (1989), UGM (1992), Virama Karya, PT (1992), Citra Mandala, PT (1993).

\section{METHOD}

\section{Construction of computer data base}

A Computer Data Base (CDB) system is a computer-assisted system for the acquisition, storage, analysis and display of land use and soil erosion. The element size of data base for this study is $200 \times 200 \mathrm{~m}^{2}$. Map digitizing system is the component that one can take existing paper maps and converted them into digital form. In IDRISI, digitizing and editing the digital maps can be supported by some software packages like TOSCA, ArcInfo and AUTOCAD (Eastman, 1992). Image processing system is allows to take raw remotely sensed imagery (such as LANDSAT, SPOT satellite imagery) and convert into interpreted map according to classification procedure.

The CDB system is constructed for processing and managing of the land use and erosion data on the study area. The input data sets are entered to the system via keyboard or through the digitization of map information. The maps which are necessarily digitized and on which the GIS is structured are the thematic maps of USLE parameters; rainfall erosivity $(R)$, soil erodibility factor $(K)$, length slope-steepness factor $(L S)$. land use factor $(C)$, and conservation factor $(P)$. Each grid-cell has an element size of $200 \times$ $200 \mathrm{ml}^{2}$. The parcel and identification number is collected and stored in attribute tables. Identification number is the reference code for the retrieval of information.

\section{Estimation of soil erosion}

In this study, the universal soil loss equation (USLE) suggested by Wischmeier and Smith (1978), was used to determine gross soil erosion in the Wonogiri catchment area. The USLE is given as:

$$
E=R \times K \times L S \times C \times P
$$

where $E$ is gross soil erosion (t/ha/yr), $R$ is rainfall erosivity (KJ/ha), $K$ is soil erodibility $(\mathrm{t} / \mathrm{KI}), L S$ is length-slope-steepness factor, $C$ is crop management factor, and $P$ is soil conservation practice factor. Determination of each factor is discussed below. 
Rainfall erosivity, $R$-factor: The $R$-factor was calculated by using equation developed in Java based on various plot studies carried out by the Soil Research Institute--Boggier, supervised by Belgian Technical Assistance under Bols (1976) as:

$R=\sum_{i=1}^{n} E I_{30,2 n}$

$E I_{30, \cdots}=6.119 R_{m,}^{1.211} N^{-0.474} R_{M A X}^{0.526}$

where $E I_{30, m}$ is mean monthly erosivity factor (KJ/ha), $R_{n}$ is monthly rainfall (cm) $N$ is number of rainfall-days in a month, $R_{\text {sux }}$ is maximum-daily-rainfall in a month $(\mathrm{cm})$.

Soil erodibility $K$-factor: The soil data in the study area were identified by using soil map from the Soil Research Institute, Bogor. It was found that, the soil in the study area are Inainly composed of Lathossols, Meditranians, Lithossols and Grumusols. The texture of the soils are composed of $15-65 \%$ of sand and $40-75 \%$ of very tine sand and silt. Organic matter content varies from $0.05 \%$ to $6.5 \%$. The soil structures are mostly fine granular, with a permeability ranges betwcen slow and moderate. Using these information, the soil erodibility factor was computed following the nomograph prepared by Wischmeier et al (1971).

Length-slope-steepness $L S$-factor: The project area is located almost entirely in fairly steep momntainous terrain, which varies from smooth urtil undulating/hilly with elevation of +127 up to $+1500 \mathrm{~m}$. The slope of the land surface in the watershed varies from $2 \%$ to steeper than $45 \%$. Combined $L S$-factor for all land units was computed following the formula suggested by (Williams and Berndt, 1972):

$L S=\sqrt{22.13}\left(0.065+0.0453 S+0.0065 S^{*}\right)$

where $L$ is slope length in $\mathrm{m}$, and $S$ is slope steepness in $\mathrm{m} / \mathrm{m}$. $L$ is determined from: $L=\frac{0.5 A}{L C H}, L C H$ is the total length of channels $(\mathrm{m})$ in the watershed, and $A$ is basin area $\left(\mathrm{m}^{2}\right)$.

Land use C-factor: The digitally classified land use was used to determine the $C$-factor values for each sub-unit land following the table provided by BPS (1989). About $85 \%$ of the total study area composed of arable land and homestead, while forests occupy less then $15 \%$. The land use are generally composed of wet rice (paddy), upland rice (gogo), soybeans, maize, groundnuts and cassava. Settlement area usually developed among the agricultural area as homestead. The $C$-factor for unit of land was estimated based on the dominant land use. The $C$-value ranges from 0 to 1 . The $C$ is highest for bare land (1.0), and lowest for lands which are fully covered with straw mulch (0.005).

Conservation practice P-factor: The $P$-factor refer to the practices on site that reduces the cffects of topography, slope length and steepness, contour strip-crop system, contouring, and terracing. The $P$ value for unit land composed of various land treatment can be estimated using formula from Williams and Berndt (1972) as:

$P=1.0 \times S R+0.30 S R W W+P_{T} \times T$ 
where $P$ is control practice factor for unit land, $S R$ is the portion of the watershed farmed with straight rows, $S R W W$ is the portion of the watershed farmed with straight rows and grassed waterways, $P_{T}$ is the erosion-control-practice factor for terracing, and $T$ is the portion of the watershed that is terraced.

Each of the USLE factor with associated attribute data was digitally encoded in GIS data base eventually to construct five thematic layers. Using multilayer procedure, gross soil erosion was computed.

\section{Sediment delivery ratio}

Originally USLE was developed based on plot scale. The application of USLE on basin scale have to be corrected with the so-called Delivery Ratio $(D R)$ (Williams and Berndt, 1972), which is defined as the ratio of sediment actually delivered (sediment yield=SY) at the basin outlet to the gross erosion $(E)$. The magnitude of the ratio for a particular basin is influenced by a wide range of geomorphological and environmental factors including the nature, extent and location of the sediment sources, the relief and slope characteristics, the drainage pattern and channel conditions, the plant cover, land use and soil texture. For the case of Wonogiri watershed, Suripin (1997) found that the $D R$ (in \%) is function of bifurcation ratio $\left(R_{b}\right)$, mean basin slope $(S$ in $\%)$, and percentage of wet land and forest $\left(W_{L}+F_{L}\right)$ as expressed:

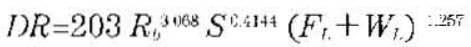

Implementation of bench terraces adjust the mean basin slope as expressed in:
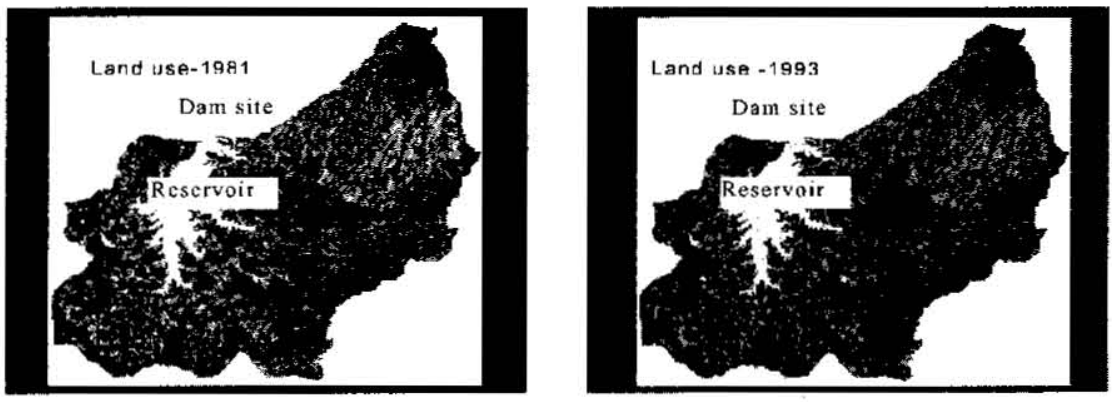

Legend

Forest
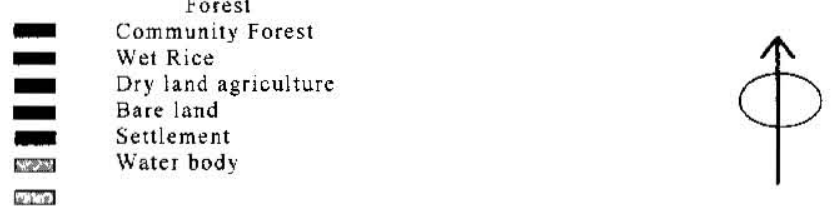

Fig. 2. Land use map of the Wonogiri watershed for the years, 1981 and 1993 
$S_{\text {ad } j}=\frac{\sum\left(A-A_{e j}\right)_{i} S_{i}}{\sum A_{i}}$

where: $S_{\text {it }}$ is adjusted mean basin slope, $A$ is sub-basin area (ha), $A_{\text {w }}$ is effective area of terraced land within sub-basin (ha), $A_{i}$ is sub-area of land plot having a slope $S_{i}$ (hid).

\section{Land use changes in the study area}

Two digital land use maps for the Wonogiri watershed for the ycar of 1981 and 1993 have bccn digitized, as presented in Figure 2. These maps were developed on the basis of aerial photographs of corresponding year at a scale of 1:50.000. The land use was classified broadly into 6 categories; forests (natural and community), wet land (paddy field), dry agricultural land, water body, and bare land.

The land use changes were then analyzed according to Figure 2. The results are presented as shown in Table 2 . Using Table 2 above, the matrix of land use change in the study area can be arranged as shown in Table 3 below:

Table 2. Land use changes in the Wonogiri catchment area, 1981 and 1993

\begin{tabular}{lrrrrrc}
\hline \multicolumn{1}{c}{ Land Use Category } & \multicolumn{2}{c}{ Area in 1981 } & \multicolumn{2}{c}{ Area in 1993 } & \multicolumn{2}{c}{ Change in ha } \\
\hline \multicolumn{1}{c}{$(1)$} & ha & $\%$ & ha & $\%$ & Decrease & Increase \\
Forests & $(2)$ & $(3)$ & $(4)$ & $(5)$ & $(6)$ & $(7)$ \\
Wet Rice & 11904 & 9.79 & 11876 & 9.76 & 28 & 4 \\
Dry Agr. Land & 22908 & 18.83 & 22912 & 18.83 & & \\
Settlement and & 62400 & 51.29 & 58744 & 48.29 & 3656 & \\
Homestead & 22484 & 18.48 & 22664 & 18.63 & & \\
Water Body & & & & & & \\
Bare Land & 168 & 0.14 & 168 & 0.14 & & \\
Comm. Forests & 1788 & 1.47 & 760 & 0.62 & 1028 & 4528 \\
Total & 0 & 0.00 & 4528 & 3.72 & & 4712 \\
\hline
\end{tabular}

Table 3. Matrix of land use change in the Wonogiri catchment area (in ha) for the years, 1981 and 1993.

\begin{tabular}{|c|c|c|c|c|c|c|}
\hline \multirow[t]{2}{*}{ Lanld use Category } & & \multicolumn{5}{|c|}{ Change to } \\
\hline & & (1) & (2) & (3) & (4) & (5) \\
\hline Forests & (1) & 0 & 0 & 0 & 28 & 0 \\
\hline WetRice & (2) & 0 & 0 & 0 & 0 & 0 \\
\hline Dry Agr. Land & (3) & 0 & 4 & 0 & 152 & 0 \\
\hline Settlement and Homestead & (4) & 0 & 0 & 0 & 0 & 0 \\
\hline Bareland & (5) & 0 & 0 & 0 & 0 & 0 \\
\hline Comm. Forests & $(6)$ & 0 & 0 & 0 & 0 & 0 \\
\hline Total & & 0 & 4 & 0 & 180 & 0 \\
\hline
\end{tabular}




\section{RESULTS AND DISCUSSION}

The gross erosion resulting from the spatial overlay of various USLE factors in the Wonogiri watershed for the period of 1981-1985 and 1990-1994 are presented in Figure 3. Table 4 represents overall erosion classes in the Wonogiri watershed for the period of 1981-1985 and 1990-1994.

From the gross erosion data (Table 4), it can be seen that the watershed experiences a very high erosion, however there has been reduction of erosion rate between the two periods. The area with gross erosion within tolerance limits $(0-10$ ton/ha $)$, and slight erosion increased from $14.04 \%$ to $14.72 \%$, and $22.40 \%$ to $24.77 \%$, respectively. While the area with moderate and very severe erosion decreased. This improvement was figured clearly from the average gross erosion for the whole of the Wonogiri watershed as given in Table 5. Figure 3 revealed that the steep sloping of dry agricultural land with no management practice are severely eroded $(>100$ ton/ha). It is also revealed that the reduction of erosion was mostly due to land use change from bare land to community forest, and due to implementation of bench terraces.

A great reduction of soil erosion was occurred in the Tirtomoyo and Upper Solo sub-basins. It is understandable since the improvement of land cover mostly took place in this two sub-basins, besides soil conservation activities were concentrated in these two sub-basins.

Table 4. Estimated gross erosion in the Wonogiri watershed for the period of 1981-1985

\begin{tabular}{cccc}
\hline $\begin{array}{c}\text { Gross erosion } \\
\text { ton/ha }\end{array}$ & Erosion class & $\begin{array}{c}\text { Area in \% } \\
1981-1985\end{array}$ & $\begin{array}{c}\text { Area in \% } \\
1990-1994\end{array}$ \\
\hline $000-010$ & within tolerant linit & 14.04 & 14.72 \\
$010-050$ & slight erosion & 22.40 & 24.77 \\
$050-100$ & moderate erosion & 13.98 & 13.63 \\
$100-250$ & severe erosion & 12.12 & 18.39 \\
$>250$ & very severe erosion & 37.46 & 28.49 \\
\hline
\end{tabular}

Table 5. Average gross erosion in sub-basin

\begin{tabular}{|c|c|c|c|c|c|c|c|}
\hline \multirow[b]{2}{*}{ Sub-basin } & \multirow{2}{*}{$\begin{array}{l}\text { Ared } \\
\text { ha }\end{array}$} & \multicolumn{3}{|c|}{$1981-1985$} & \multicolumn{3}{|c|}{$1990-1994$} \\
\hline & & $\begin{array}{c}\mathrm{E} \\
\mathrm{t} / \mathrm{ha} / \mathrm{yr}\end{array}$ & $\begin{array}{c}\text { DR } \\
\%\end{array}$ & $\begin{array}{c}\text { SY } \\
\text { tha/yr }\end{array}$ & $\begin{array}{c}\mathrm{E} \\
\mathrm{t} / \mathrm{ha} / \mathrm{yr} \\
\end{array}$ & $\begin{array}{c}\mathrm{DR} \\
\%\end{array}$ & $\begin{array}{c}\text { SY } \\
\mathrm{t} / \mathrm{ha} / \mathrm{yr}\end{array}$ \\
\hline Keduang & 41736 & 167,98 & 19.55 & 32.84 & 159,33 & 19.24 & 30.66 \\
\hline Tirtomoyo & 22936 & 544,10 & 45.09 & 245.33 & 354,04 & 38.40 & 135.95 \\
\hline Beling & 6504 & 261,17 & 13.47 & 35.18 & 213,50 & 11.60 & 24.76 \\
\hline Uppe Solo & 20352 & 616,97 & 36.88 & 227.44 & 335,35 & 29.42 & 98.66 \\
\hline Alang & 16380 & 176,45 & 27.21 & 48.01 & 159,81 & 22.98 & 36.72 \\
\hline Wuryantoro & 13744 & 337,55 & 12.38 & 41.79 & 297,06 & 10.81 & 32.11 \\
\hline Wonogiri Basin & 121652 & 323,26 & 33.61 & 108.64 & 228,43 & 27.38 & 62.55 \\
\hline
\end{tabular}

$\mathrm{E}=$ gross crosion from the GIS technique, $\mathrm{DR}=$ deposition rate, $\mathrm{SY}=$ sediment yicld 

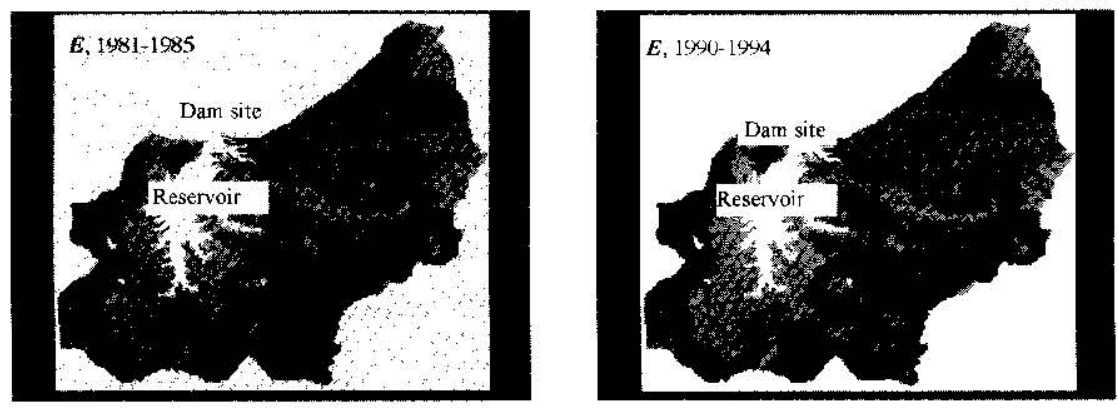

Legend
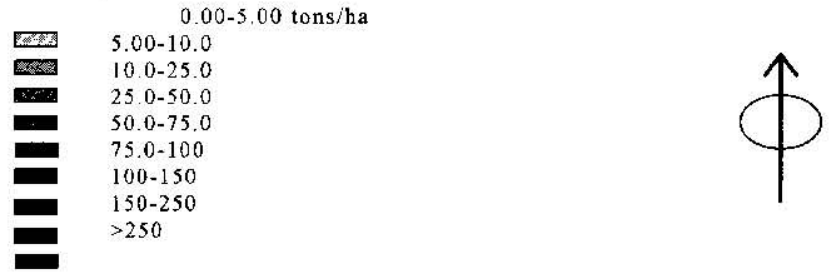

Fig. 3. Syatial and temporal gross soil erosion $E$ (1.ms/ha/year) of the Wonogiri watershed for the period 1981-1985 and 1990-1994

Land cover improvement reduces not only soil erosion but also surface runoff (Banasik, 1989; Roger et al., 1996). Analysis of streamflow in the Wonogiri watershed shows that the five-year moving average of the ratio of runoff-rainfall decreased from 0.71 in 1981-1985 to 0.54 in 1990-1994. The subsequent effects of this phenomena is than to reduce sediment delivery ratio, on the other words to reduce sediment yield.

The results of the present study are in line with the measured reservoir deposition (Table 1). The reduction of reservoir deposition rate was in accordance with the decreasing crosion rate on the catchment. This decrease may be overestimated if only caused by land use changes. The deviation in gross crosion may much due to soil conservation which took place during the period of 1988-1994.

\section{CONCLUSION AND SUGGESTION}

Land use/cover plays a critical role in the overall catchment area management project. Population pressure, however, has broken the golden rule of soil conservation: keeping continuous land cover. As consequence, soil is degraded seriously; soil erosion rises remarkably, and soil fertility decreased. Further consequence, the Gajah Mungkur reservoir was silted up seriously.

The results of this study more or less fit with the measured reservoir dcposition. The rate of deposition was decreased during the last decade in accordance to the land use 
improvement and the effort of land rehabilitation/soil conservation. The alteration of land cover from bare land/dry agricultural land has reduced soil erosion/sediment yield and improve water conservation as well. Population pressure and food demand, however, limit further alteration of existing farmland (dry agricultural land) to nonfarm land that provides land cover permanently.

The results of this study can be used as guidelines to implement various soil conservation measures for different sub-catchment on priority basis, and to improve the strategy of watershed management.

It is suggested that the soil conservation should be focused not only on physical measures, but also non-physical activities. The latter is aimed to improve the farmer income as weil as their awareness to the natural resources and the environment. The constrains faced in this area are the high pressure population with low income and low skill (education level), and limitation of the agricultural land. They are shortage of food and fire wood, and therefore, destruction of land by men is apparcnt as they cultivate, graze, and cut-down trees indiscriminately. Continuous guidance and counseling to improve farmers skill and awareness on the sustainability of natural resources have to be carried out. Without participation of the local commurity, the conservation efforts would be ineffective.

\section{REFERENCES}

Banasik, Kazimicrz 1989 Estimation of Effects of Land Ise Changes on Storm Event Sediment Yield from a Small Watershed. In "Sedinent. Transport Modelling", Proceeding of the intemational Symposium. Wand, S. Y. Sam, ed. ASCE, New York, 741.746

Bols, P. L. 1976 The iso-crodent map of .Tava and Madura. Belgian Technical Assistance Project ATA 105, Soil Research Institutc, Boggier, [rodonesia, $39 \mathrm{pp}$

BPS 1989 Wenitoring of Erosion on Wonogiri Reservoir. Final Report., Dir. (ien. Water Res., PIPWSBS, Solo. 193 pp (in Indonesian)

Citra Mandala Agritrans, P. T. 1993 Monitoring of Sedimentalion on Wonogiri Reservoir and Colo Weir. Dep. Public Works, Dir. Gen. Water Res., (I'I'WSBS), Surakarta. 68 pp (in Intionesirn)

Eastman, J. R. 1992 IDRISI, vers. 4. Calrk Univ. Grad. School of Massachusetts LSA P4-PU 1986 Monitoring of Erosion/Sedimentalion in Wonogiri Basin. Dep. Pullic: Works, Dir. Gen of Water Res., PIPWSBS, Surakarta. $286 \mathrm{pp}$ (in Indonesian)

Roger, A. Kuhle. et al. 1996 Effects of land use changes on sediment transport in Goodwecn Creek. Whater Resources Research, 32 (10), 3189-3196

Suripin 1997 Sediment Yield Prediction with USLE for Basin Scale. Seminar in Dept. of Cjv. F.ng. Diportegoro University, Serrarang, February 15, 1997

UGM 1981 Monitoring and Study of Wonogiri Reservoir Sedimentation. Dep. Public Works, DGWS, PIPWSBS Surakarta. (in Indonesian)

Virama Karya, PT. 1992 Reviscd Operation and Maintenance Rules, and Calibration of Wonogiri Reservoir and Colo Weir. Dep. Public Works, DGWS. PIPWSBS Surakarta. (in Indonesian)

Williams, J. R and H. D. Berndt, 1972 Sediment Yield Compuled with Universal Soil Loss Equation. $J$. Hydr. Div., 98 (HY12), 2087-2098

Wischmeier, W. H. and D. D. Smith 1978 Predicting Rainfall Erosion Losses - A Guide to Conservation Planning. USDA Agriculture Handbook, 537, 58

Wischmeier, W. H., C. B. Johnson and B. V. Cross 1971 A Soll Erodibility Nomograph for Farmland and Construction Sites. J. Soil and Waler Conser. 26, 189-190. 